\title{
Analysis of melanopsin gene expression in the rabbit retina at different ages
}

\author{
M.M. Lira-Carrera, B.E. Gutiérrez-Amavizca, L.J. Álvarez-Araujo, \\ M. Aguirre-Ramírez and J.A. Pérez-León \\ Departamento de Químico-Biológicas, Instituto de Ciencias Biomédicas, \\ Universidad Autónoma de Ciudad Juárez, Ciudad Juárez, Chihuahua, México \\ Corresponding autor: J.A. Pérez-León \\ E-mail: alberto.perez@uacj.mx
}

Genet. Mol. Res. 16 (3): gmr16039767

Received June 29, 2017

Accepted August 29, 2017

Published September 27, 2017

DOI http://dx.doi.org/10.4238/gmr16039767

Copyright $(92017$ The Authors. This is an open-access article distributed under the terms of the Creative Commons Attribution ShareAlike (CC BY-SA) 4.0 License.

\begin{abstract}
Melanopsin is the photopigment of intrinsically photosensitive retinal ganglion cells that mediate non-visual responses to light. The aim of this study was to describe and analyze melanopsin gene expression in the rabbit retina at different ages and compare its expression with the prototypic gene of retinal ganglion cells (Thy-1 gene). Expression levels of OPN4, Thy-1, and GADPH genes were measured by real-time PCR at 3, 4, 8, 11, 12, 17, 19, 20, 23, 27, 32, and 47 postnatal days. We also regrouped the days before and after day 12 of life (pre-photic and post-photic stage, respectively). Average expression of the OPN4 gene between days was similar $(\mathrm{P}=0.713)$, but was statistically different in the Thy-1 gene $(\mathrm{P}=0.004)$. Also, no significant differences were found in $O P N 4$ gene expression pre-photic and post-photic stage $(\mathrm{P}=0.629)$; however, Thy-1 expression was higher in the pre-photic stage, almost double, than in the post-photic stage, with significant differences $(\mathrm{P}=0.001)$. This is the first report describing $O P N 4$ gene expression in the rabbit retina at different ages. We demonstrated that the OPN4 gene is constantly expressed at all
\end{abstract}

Genetics and Molecular Research 16 (3): gmr16039767 
early stages, even before the onset of photoentrainment by the pups and that Thy-1 and OPN4 gene expressions are out of phase.

Key words: Intrinsically photosensitive retinal ganglion cell; Retina; Gene expression; Melanopsin; Rabbit

\section{INTRODUCTION}

The mammalian retina contains three types of photoreceptors: two are the classical visual photoreceptors (cones and rods), and the third one is the non-visual photoreceptor called intrinsically photosensitive retinal ganglion cell (ipRGC). The three of these types of photoreceptor cells transform the light stimulus into an electrical signal that leads a nerve impulse carrying out sensory information from the retina to the encephalon. The pigments of visual photoreceptors, conopsin (cones) and rhodopsin (rods), have been fully described, as well as characterization of the phototransduction process by these sensory neurons. However, ipRGC uses a different photopigment called melanopsin (OPN4), which is less sensitive to light responding more slowly to light and has a role in distinct physiological processes influenced by light. While rods and cones transduce light stimuli for vision, ipRGC does not participate in forming images (Provencio et al., 2002).

The ipRGC forms a rare subpopulation of ganglion cells $(<5 \%$ in primates, roughly $2 \%$ in rodents), whose main function is the non-visual responses to light: the photoentrainment of circadian rhythm, pupillary constriction (Van Gelder, 2001), light-induced melatonin suppression, sleep (Lupi et al., 2008), and other behavioral and physiological functions (Tsai et al., 2009). Besides, ipRGCs also have the unique feature to project directly to the suprachiasmatic nuclei (SCN) of the hypothalamus through a monosynaptic pathway known as the retinohypothalamic tract (RHT); at least it has been described for rodents (Sand et al., 2012).

Melanopsin, a homolog of rhodopsin and conopsin, was found in 1998 by Provencio, on the "dermal melanophores" from amphibian skin that darken in response to light (Daniolos et al., 1990). Besides being located in the retina and dermal melanophores, melanopsin can be localized in various tissues in amphibians, including deep brain nuclei, and iris (Provencio et al., 1998). The melanopsin gene (OPN4) and protein were also found in various mammalian species such as mice, monkeys, and humans (Provencio et al., 2000). Since its discovery, the presence and activity of melanopsin have been described within the retina of at least one species of each of the group of vertebrates. Furthermore, there is an established classification of several ipRGC subtypes in mice and rats (Sand et al., 2012; Hughes et al., 2016) and in humans and macaques (Liao et al., 2016).

To date, no studies have reported the expression of melanopsin in the rabbit retina, even though rabbit pups (kits) have been viewed as an excellent natural model of synchronization of rhythms by food and its posterior shift to photoentrainment (Gonzalez-Mariscal et al., 2016). The female rabbit breastfeeds kits once a day, they suckle up to $35 \%$ of their body weight every $24 \mathrm{~h}$ for 3-5 min and the mother keeps in darkness throughout the lactation (Caba et al., 2008). When young rabbits leave the burrow at 2 weeks of age, is when they are exposed to light and as a result, they open their eyelids.

The activity of the kits is not synchronized with the light-dark cycle of day and night, but by the breastfeeding from the mother (Rapisardi et al., 1975; González-Mariscal et al., 2016). Therefore, it would be unlikely that any photopigment involved in the photoentrainment

Genetics and Molecular Research 16 (3): gmr16039767 
of the circadian rhythm can be expressed at these early stages of development in rabbit when is well-known that their circadian rhythm is set by nursing from the mother. However, there are no studies that strengthen or reject this hypothesis. A first approach to provide evidence regarding this point is to describe the temporal profile expression of the melanopsin gene in the rabbit retina. Thus, the aim of this article was to describe the expression of the OPN4 gene in the rabbit retina during early development for establishing a correlation between that expression and the age of the rabbit.

\section{MATERIAL AND METHODS}

Twenty-four New Zealand rabbits (Oryctolagus cuniculus) were used in this project. All animal procedures were performed with the Guide for the Care and Use of Laboratory Animals published by the US National Institutes of Health and were approved by the Institutional Animal Care and Use Committee (Comité de Bioética de la Universidad Autónoma de Ciudad Juarez, UACJ). All efforts were made to minimize suffering. The animals were raised at Instituto de Ciencias Biomédicas - UACJ animal house, kept at 12/12-light /dark cycle, and used in physiological experiments not related to this study. We picked animals up from postnatal days $3,4,8,11,12,17,19,20,23,27,32$, and 47. Following general sedation, they were euthanized by an intracardial injection of anesthetics (sodic Pentobarbital solution). Both eyes were enucleated, and the retinas were dissected free of phosphate-buffered saline $(0.9 \% \mathrm{NaCl}$ in $0.1 \mathrm{M}$ sodium phosphate, $\mathrm{pH} 7.4)$. The retinas from two rabbits were included per group ( $\mathrm{N}=4$ per group).

Total retinal RNA was isolated using the Trizol ${ }^{\mathrm{TM}}$ technique (Chomczynski and Sachi, 1987). RNA quality was analyzed on a $0.8 \%$ agarose gel and quantified using a Nanodrop spectrophotometer (Thermo-Fisher). A sample of $1 \mu \mathrm{g}$ RNA was reverse transcribed with the MMLV Reverse Transcriptase kit (Promega), and the resulting cDNA $(1 \mu \mathrm{g})$ was used for polymerase chain reaction (PCR) using specific primers for the rabbit OPN4 gene, the ganglion cell-specific-Thy-1 gene, and the constitutive GAPDH gene. PCR primers were designed in our laboratory using the FAST-PCR software: OPN4 (forward 5'-ATTATCAACCTCGCGG TCAG-3', reverse 5'-CCGTCAGTGTGATCATGGAG-', expected size 163 bp); Thy-1 (forward 5'-GCTGCTGACAGTCTTGCAGGTG-3', reverse 5'-ACGCGCAGTTCGCAGGTGTA -3', expected size $297 \mathrm{bp}$ ), and GADPH (forward 5'-AGGTCATCCACGACCACTTC-3', reverse 5'-GTGAGTTTCCCGTTCAGCTC-3', expected size 204 bp). PCR OPN4 conditions consisted of an initial denaturation at $95^{\circ} \mathrm{C}$ for 3 min followed by 35 cycles of denaturation at $95^{\circ} \mathrm{C}$ for $60 \mathrm{~s}$, annealing at $58.9^{\circ} \mathrm{C}$ for $30 \mathrm{~s}$, and extension at $72^{\circ} \mathrm{C}$ for $30 \mathrm{~s}$, and a final elongation at $72^{\circ} \mathrm{C}$ for $4 \mathrm{~min}$. The annealing temperatures for Thy-1 and GADPH genes were $64.3^{\circ}$ and $64^{\circ} \mathrm{C}$, respectively.

The identity of expected amplicons was verified by agarose gel electrophoresis. PCR products were used for cloning and sequencing for further identification comparing the obtained sequences with those retrieved from GenBank with the aid of the Clustal W 2.0 software. All sequences matched 100\%. Quantitative PCRs were performed using the Sybr Green Master Mix (Applied Biosystems) in a MyiQ2 (BioRad) Thermal Cycler, using $1 \mu \mathrm{g}$ cDNA as template. Gene expression (number of copies for each amplicon) was compared using the Kruskal-Wallis test and the Mann-Whitney U-test and ANOVA. Statistical estimates were assayed using the SPSS v 20.0 software. A P $<0.05$ was considered statistically significant.

Genetics and Molecular Research 16 (3): gmr16039767 


\section{RESULTS}

The expression of $O P N 4, T h y-1$, and GADPH genes in the rabbit retina measured as the number of transcripts detected by qPCR by day is shown in Table 1 .

Table 1. Expression of $O P N 4, T h y-1$, and GADPH genes in the rabbit retina on different days of life.

\begin{tabular}{l|c|c|c}
\hline Day & OPN4 gene $(\mathrm{N}=4)$ & Thy- 1 gene $(\mathrm{N}=4)$ & GADPH gene $(\mathrm{N}=4)$ \\
\hline 3 & $15395.0 \pm 15528.9$ & $15566.7 \pm 1700.9$ & $24200.0 \pm 24565.1$ \\
\hline 4 & $54373.3 \pm 41788.7$ & $37200.0 \pm 48841.6$ & $31917.5 \pm 44563.3$ \\
\hline 8 & $41430.0 \pm 32834.5$ & $35933.3 \pm 4660.8$ & $13190.0 \pm 11938.6$ \\
\hline 11 & $49903.3 \pm 38956.4$ & $38100.0 \pm 6646.8^{* *}$ & $25287.5 \pm 17119.5$ \\
\hline 12 & $28802.5 \pm 27421.3$ & $28133.3 \pm 5093.5^{* *}$ & $29270.0 \pm 41165.0$ \\
\hline 17 & $33795.0 \pm 34541.4$ & $13566.7 \pm 1150.4$ & $51047.5 \pm 45889.0$ \\
\hline 19 & $47130.0 \pm 39710.9$ & $13266.7 \pm 1656.3$ & $178062.5 \pm 315504.8$ \\
\hline 20 & $27085.0 \pm 27395.5$ & $32400.0 \pm 9333.8$ & $2195.0 \pm 9606.6$ \\
\hline 23 & $36560.0 \pm 31086.9$ & $11393.3 .0 \pm 1861.8$ & $11110.0 \pm 11261.8$ \\
\hline 32 & $29233.3 \pm 17154.1$ & $31533.3 \pm 5179.1$ & $16226.7 \pm 16306.9$ \\
\hline 47 & $16333.3 \pm 21193.9$ & $14100.0 \pm 707.1$ & $21270.0 \pm 29356.9$ \\
\hline P value & $73300.0 \pm 57558.5$ & $12950.0 \pm 2333.5^{* *}$ & 0.838 \\
\hline
\end{tabular}

$* \mathrm{P}<0.05$ ANOVA among groups; $* * \mathrm{P}<0.05$ Games-Howell post-hoc analysis test.

The average expression of the OPN4 gene among days was similar $(\mathrm{P}=0.713)$. Nevertheless, Thy-1 gene expression was statistically different between days $(\mathrm{P}=0.004)$; the gene expression level at day $47(12950.0 \pm 2333.5)$ was lower than at $8(35933.3 \pm 4660.8 ; \mathrm{P}=0.047)$, and 11 postnatal days $(38100.0 \pm 6646.8 ; \mathrm{P}=0.045)$. Besides, the expression of OPN4, Thy-1, and $G A P D H$ genes for different days was regrouped, considering the physiological changes of the rabbit related to environmental exposure. Given the fact that kits open their eyes after 2 weeks of age, and thus the retina is exposed to light for the first time, we evaluated the expression of these genes in the pre-photic stage (days 3-12) and post-photic stage (days 17-47) (Table 2).

Table 2. Expression of $O P N 4$, Thy-1, and GAPDH genes on different days of life in the rabbit retina.

\begin{tabular}{l|c|c|c}
\hline Gene & Pre-photic stage (days 3-12) $(\mathrm{N}=20)$ & Post-photic stage (days 17-47) $(\mathrm{N}=28)$ & P value \\
\hline OPN4 & $40295.3 \pm 30494.2$ & $40429.3 \pm 6652.2$ & 0.629 \\
\hline Thy-1 & $31273.3 \pm 9820.4$ & $18640.0 \pm 9396.3$ & $0.001^{*}$ \\
\hline GADPH & $29080.67 \pm 30115.1$ & $61918.2 \pm 152661.2$ & 0.449 \\
\hline
\end{tabular}

*P $<0.05$ Mann-Whitney U-test.

OPN4 and GADPH gene expression levels before and after day 12 were similar $(\mathrm{P}=0.629$ and $\mathrm{P}=0.449$, respectively); however, Thy- 1 gene expression was statistically different between the pre-photic and post-photic stage $(\mathrm{P}=0.001)$, which was higher, almost double in the prephotic stage (mean 31273.3) than the post-photic stage (mean 18640.0). Finally, we analyzed the OPN4 and Thy-1 genes according to their expression levels from days 3 to 47, finding significant differences (mean $35687.2 \pm 30673.9$ vs $24160.0 \pm 11463.5$, respectively; $\mathrm{P}=0.034$ ).

\section{DISCUSSION}

The rabbit is a purely nocturnal animal before weaning. The mother rabbit feeds their kits only at night. The kits are not exposed to light; meanwhile, they are kept inside the burrow (González-Mariscal et al., 2016), and rather the feeding plays the role of pacemaker for the circadian rhythm. This synchronization by food is evidenced by an anticipatory increase in the 
active behavior a couple of hours before the breastfeeding. As an anatomical correlate of this, it has been reported that the activity of c-FOS in the kit's forebrain is increased by nursing (González-Mariscal et al., 2009, 2016). Thus, there is no doubt about the predominant role of nursing for entraining circadian rhythm at this developmental stage. On the other hand, there is no evidence for circadian rhythm photoentrainment during the perinatal development of rabbit, even though a study reported the increased activity of c-FOS in the SCN induced by flashing light at postnatal days 1, 9, and 19 (Juárez et al., 2013). Before postnatal day 10, the kits are blind, and there are still no synapses among cones and rods and interneurons (Masland, 1977; González-Mariscal et al., 2009, 2016).

In trying to explain those data, it would be necessary considering the presence and activity of ipRGCs; however, to date, no study has been published regarding this cell type within rabbit retina. We propose that the gene expression we measured for OPN4 makes feasible the participation of melanopsin-containing cells in the light responses measured during early development in the rabbit (Juárez et al., 2013), and thus our data add evidence for these non-visual photoreceptors in this retina. When the kit leaves the burrow, its circadian rhythm turns to be regulated by the light-dark cycle. It is very well-known that the Thy-1 gene is the representative of ganglion cells, which are the first cell type to differentiate within the retina (Barnstable and Dräger, 1984). However, the comparison with time-expression of the OPN4 gene in the rabbit retina had not been developed before. Our preliminary results demonstrated that the OPN4 gene is expressed before and at higher levels than the Thy-1 gene, during the first 120 days of life as we could measure. Therefore, the melanopsin protein could be proposed as present in more ganglion cells than Thy-1, or perhaps melanopsin might be expressed in another cell type aside ganglion cells. It is important to highlight that Thy-1 expression was higher at days 8 and 11, which corresponds just before exposure to light, which was statistically significant compared to the level of expression at day 47. This increase in Thy-1 expression corresponds to the reported age for the increase in light-evoked activity of ganglion cells and the establishment of retinal circuits in rabbit retina (Masland, 1977).

\section{CONCLUSIONS}

We showed that $O P N 4$ gene expression reaches high levels before the prototypical gene of ganglion cells (Thy-1). This could mean that these cells expressing melanopsin are primarily due to as photoreceptors (primary sensory neurons) rather than being ganglion cells (projecting neurons). According to our results, we can finally infer that the OPN4 protein, namely melanopsin, is constantly expressed at all early stages and that there are cells expressing melanopsin that are not ganglion cells. In conclusion, the OPN4 gene is constantly expressed at all early stages, even before the onset of photoentrainment by the pups. Noteworthy, Thy1 and OPN4 gene expressions are out of phase the one from OPN4 always reaching higher levels before that of Thy-1. It is necessary to confirm the expression of the protein either by immunohistochemistry or western blot, but so far there are no antibodies against rabbit melanopsin.

\section{Conflicts of interest}

The authors declare no conflict of interest.

Genetics and Molecular Research 16 (3): gmr16039767 


\section{ACKNOWLEDGMENTS}

B.E. Gutiérrez-Amavizca is the recipient of a postdoctoral scholarship from the National Council of Science and Technology (CONACYT). Research supported by Programa Integral de Fortalecimiento Institucional (PIFI) 2007-2008, 2909 5001-004-09 and CONACYT Ciencia Básica 2008-01-106298, Donativo PROMEP a Nuevos PTC, 2009 UACJ-PTC-185, and PROMEP Apoyo a Cuerpos Académicos 2013. We acknowledge the technical assistance of Valeria Calderon, Departamento de Ciencias Veterinarias - ICB.

\section{REFERENCES}

Barnstable CJ and Dräger UC (1984). Thy-1 antigen: a ganglion cell specific marker in rodent retina. Neuroscience 11: 847-855. https://doi.org/10.1016/0306-4522(84)90195-7

Caba M, Tovar A, Silver R, Mogado E, et al. (2008). Nature's food anticipatory experiment: entrainment of locomotor behavior, suprachiasmatic and dorsomedial hypothalamic nuclei by suckling in rabbit pups. Eur. J. Neurosci. 27: 432-443. https://doi.org/10.1111/j.1460-9568.2008.06017.x

Chomczynski P and Sacchi N (1987). Single-step method of RNA isolation by acid guanidinium thiocyanate-phenolchloroform extraction. Anal. Biochem. 162: 156-159. https://doi.org/10.1016/0003-2697(87)90021-2

Daniolos A, Lerner AB and Lerner MR (1990). Action of light on frog pigment cells in culture. Pigment Cell Res. 3: 38-43. https://doi.org/10.1111/j.1600-0749.1990.tb00260.x

González-Mariscal G, Jiménez A, Chirino R and Beyer C (2009). Motherhood and nursing stimulate c-FOS expression in the rabbit forebrain. Behav. Neurosci. 123: 731-739. https://doi.org/10.1037/a0016487

González-Mariscal G, Caba M, Martínez-Gómez M, Bautista A, et al. (2016). Mothers and offspring: The rabbit as a model system in the study of mammalian maternal behavior and sibling interactions. Horm. Behav. 77: 30-41. https:// doi.org/10.1016/j.yhbeh.2015.05.011

Hughes S, Jagannath A, Rodgers J, Hankins MW, et al. (2016). Signalling by melanopsin (OPN4) expressing photosensitive retinal ganglion cells. Eye (Lond.) 30: 247-254. https://doi.org/10.1038/eye.2015.264

Juárez C, Morgado E, Meza E, Waliszewski SM, et al. (2013). Development of retinal projections and response to photic input in the suprachiasmatic nucleus of New Zealand White Rabbits. Brain Res. 1499: 21-28. https://doi. org/10.1016/j.brainres.2013.01.010

Liao HW, Ren X, Peterson BB, Marshak DW, et al. (2016). Melanopsin-expressing ganglion cells on macaque and human retinas form two morphologically distinct populations. J. Comp. Neurol. 524: 2845-2872. https://doi.org/10.1002/ $\underline{\text { cne. } 23995}$

Lupi D, Oster H, Thompson S and Foster RG (2008). The acute light-induction of sleep is mediated by OPN4-based photoreception. Nat. Neurosci. 11: 1068-1073. https://doi.org/10.1038/nn.2179

Masland RH (1977). Maturation of function in the developing rabbit retina. J. Comp. Neurol. 175: 275-286. https://doi. org/10.1002/cne. 901750303

Provencio I, Jiang G, De Grip WJ, Hayes WP, et al. (1998). Melanopsin: An opsin in melanophores, brain, and eye. Proc. Natl. Acad. Sci. USA 95: 340-345. https://doi.org/10.1073/pnas.95.1.340

Provencio I, Rodriguez IR, Jiang G, Hayes WP, et al. (2000). A novel human opsin in the inner retina. J. Neurosci. 20: 600-605.

Provencio I, Rollag MD and Castrucci AM (2002). Photoreceptive net in the mammalian retina. This mesh of cells may explain how some blind mice can still tell day from night. Nature 415: 493. https://doi.org/10.1038/415493a

Rapisardi SC, Chow KL and Mathers LH (1975). Ontogenesis of receptive field characteristics in the dorsal lateral geniculate nucleus of the rabbit. Exp. Brain Res. 22: 295-305. https://doi.org/10.1007/BF00234771

Sand A, Schmidt TM and Kofuji P (2012). Diverse types of ganglion cell photoreceptors in the mammalian retina. Prog. Retin. Eye Res. 31: 287-302. https://doi.org/10.1016/j.preteyeres.2012.03.003

Tsai JW, Hannibal J, Hagiwara G, Colas D, et al. (2009). Melanopsin as a sleep modulator: circadian gating of the direct effects of light on sleep and altered sleep homeostasis in Opn4(-/-) mice. PLoS Biol. 7: e1000125. https://doi. org/10.1371/journal.pbio.1000125

Van Gelder RN (2001). Non-visual ocular photoreception. Ophthalmic Genet. 22: 195-205. https://doi.org/10.1076/ opge.22.4.195.2215

Genetics and Molecular Research 16 (3): gmr16039767 